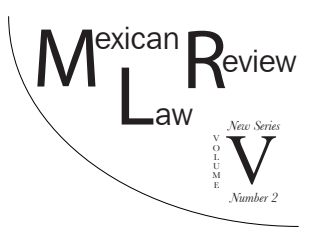

\title{
WHY HAS THE TRANSITION TO DEMOGRACY LED THE MEXICAN PRESIDENTIAL SYSTEM TO POLITICAL INSTABILITY? A PROPOSAL TO ENHANCE INSTITUTIONAL ARRANGEMENTS*
}

\author{
Jorge Arturo Álvarez TovaR**
}

\begin{abstract}
Over the past two decades, Mexico has gone from an authoritarian regime to an electoral democracy. Although this change is undoubtedly positive, the institutional engineering in place and the balance of power among institutions has led to increased political instability and a latent risk of political paralysis. There is substantial literature asserting that these problems may be connected to the core characteristics of presidential systems; however, I demonstrate that in the Mexican case, it is also due to the electoral rules derived from the reforms of the 1990s and the subsequent electoral results. To substantiate this claim, I present the historical conformation of the presidential, political and electoral systems, as well as the balance of power derived from later system structures and the problems that can trigger instability. Finally, in response to the vast amount of literature that asserts that presidential systems generally shift to a parliamentary or semi-presidential system to perform better, I present an original formula based on relatively simple and feasible political reforms that can enhance the Mexican presidential system and prevent political paralysis.
\end{abstract}

Key WoRDs: Balance of power, democracy, presidential, parliamentary, amd Semi-presidential systems, institutional arrangements.

Resumen. Durante las dos décadas pasadas, México ha transitado de un régimen autoritario a una democracia electoral. Aun y cuando dicho cambio

* Acronyms and terms: COFIPE, Federal Code of Institutions and Electoral Procedures; IFE, Federal Electoral Institute; MCs, Members of Congress; MSD, Multi Seat District; PAN, National Action Party; PRI, Institutional Revolutionary Party; PRD, Democratic Revolutionary Party; PR, Proportional Representation; PVEM, Green Party; SSD, Single Seat District; TEPJF, Federal Electoral Court (also known as TRIFE).

** Master of Public Administration (MPA) in Public Policy and Management from The London School of Economics and Political Science; former member of Mexican Senate Civil Service and Chief of Staff of Foreign Affairs Committee; currently, Regulation and Institutional Relations Manager at Alestra, Alfa Group. 
es sin duda positivo, el entramado institucional conjuntamente con el balance de poder entre instituciones ha generado en el sistema inestabilidad politica creciente y riesgo latente de parálisis institucional. Vasta literatura señala que estos problemas pueden ser originados por las características propias de los sistemas presidencialistas, sin embargo demostraré que para el caso mexicano este es resultado fundamentalmente de las reglas electorales derivadas de las reformas de los años noventa, y los resultados derivados de estas reformas. Para fundamentar esta aseveración, en este trabajo presentaré desde una perspectiva histórica la configuración de nuestros sistemas presidencialista y electoral. Asimismo mostrare el balance de poder derivado de la configuración de los sistemas mencionados y los peligros generados por esta configuración que detonaron la inestabilidad. Finalmente y contrario a la vasta literatura que asegura que los sistemas presidenciales están condenados a transitar a un sistema parlamentario o semi-parlamentario a fin de operar de mejor manera, presentare una formula innovadora basada en una relativamente simple y posible reforma política que reforzara el sistema presidencialista mexicano y ayudara a evitar la parálisis politica.

Palabras clave: Balance de poder, democracia, sistemas presidencial, parlamentario y semi-presidencial, arreglos institucionales.

TABLE OF CONTENTS

I. INTRODUCTION ................................................................... 279

II. Presidential Systems ............................................................. 280

III. Transition to Democracy: Evolution of Institutional Arrangements and the Balance of Power.

1. Post-Revolutionary Period: Conformation of Presidential Power.

2. Role of Parties and Congress in the Process of Democratization

3. Electoral Reforms of the 1990s and the Subsequent Balance of Power

IV. Remaining Threats to Mexican Presidentialism: A Proposal to Enhance the System

1. Remaining Threats to Democracy in Mexico 292

2. Enhancing the Mexican Presidential System 297

A. Endowing Legitimacy to the Executive Mandate................ 298

B. Reorienting Legislators towards Their Constituencies ........ 299

C. Fostering Cooperation among Branches .......................... 300

V. Gonclusions …................................................................ 303 


\section{INTRODUCTION}

Many scholars have argued that Mexico completed its transition to democracy in the year 2000 when the country experienced its first alternation in power. This was an important feature which Mexico was lacking in order to be classified as a democratic country. Although there is some debate as to what type of democracy Mexico is, this discussion is outside the scope of this article.

This article argues that even though the Mexican presidential system has been moving forward over the last two decades to enhance democracy and its political institutions, there are still some latent dangers due to the institutional arrangements of the system, some of which are derived from the historical conformation of the regimes and others from core characteristics of the presidential system. Specifically, the main claim of the article at hand is that a transition to democracy can lead the Mexican system to the real possibility of political paralysis characterized by legislative gridlock regarding structural reforms and the risk of ungovernability, generated by the separation of powers and the absence of cooperation among institutions. To substantiate this claim, this article studies the shift in the balance of power among institutions - as a consequence of the electoral results of 1997 - combined with the institutional arrangements set in place: plural rule for electing the president, the absence of reelection for legislators, and the separation of powers with no incentives for cooperative games.

As citizens decide on the distribution of power by casting their votes, it is possible to engineer a policy-oriented solution to the problem by improving existing institutional arrangements. More specifically, this article argues that the following three specific reforms to institutional arrangements are required to enhance governability in Mexico: (i) establishing a second round runoff for electing the president; (ii) reinstating legislative reelection; and (iii) introducing an alternative mechanism to foster cooperation among institutions. We believe these reforms will give way to a different set of arrangements that will lead to enhanced governability.

In the first section of this article, I will briefly discuss the core institutional arrangements which define presidential systems. I will also present some of the debate in literature regarding the dangers that can derive from such institutional engineering. Throughout the discussion, I will sometimes compare this system with others for the sake of clarity.

The second section of this article provides a brief overview of the development of the institutional arrangements under Mexico's post-revolutionary presidential regime. I point out that before the transition to democracy there was a significant gap between de jure and de facto powers. I then describe the role of the opposition in the democratization process, to finally analyze the evolution of electoral engineering from 1990 to 2006, in which major reforms were made to the system to bring about an important shift in the balance 
of power by democratizing institutions and effectively separating the powers central to presidential systems.

In the third section, I argue that the new configuring derived from electoral reforms, combined with old institutional and constitutional arrangements, left the system exposed to: (i) legislative gridlock (in terms of structural reforms), (ii) political instability, due to low legitimacy of mandate; and (iii) ungovernability, making it more difficult for the government to put forward and successfully champion its agenda. The last part of this section focuses on providing what, in my perspective, are the reforms needed in terms of institutional engineering to overcome the perils that can still be found in the system.

Although I am well aware of many other things deemed necessary to enhance democracy and governability, the rationale behind this analysis is that addressing the proposed reforms will generate a more balanced and standardized political system and, more importantly, it will create a system aimed at fulfilling citizens' needs.

\section{Presidential Systems}

In the institutional engineering of democratic political regimes, countries can be classified in one of two categories, often referred to as "pure" regimes:" parliamentary and presidential. Many scholars have argued that the latter type of system tends to be more unstable than the former and therefore, parliamentary systems are considered superior. ${ }^{2}$ Some empirical analyses have suggested that parliamentary regimes are longer-lived and democracy is more likely to survive under such regimes. ${ }^{3}$ Other authors have shown that whether countries opt for one system or the other, they tend to add certain variations to it. This variability has led to a somewhat inadequate definition of these regimes. The most distinct spin-off of the presidential system was classified by Duverger in 1970 as a semi-presidential system. ${ }^{4}$

Whether there are three main criteria for defining presidential systems ${ }^{5}$ or two features that stand out of such systems, ${ }^{6}$ most scholars agree that these

${ }^{1}$ Alfred C. Stepan \& Cindy Skach, Constitutional Frameworks and Democratic Consolidation: Parliamentarism versus Presidentialism, 46 (1) World Politics 1, 1-22 (1993).

${ }^{2}$ In the debate of political regimes, there is no clear consensus on which type of system performs the best. However, it seems to be widely accepted that the success of a system in a country or a region depends on many different factors, such as historical background, education, economic stability, inequality, number of parties, and so forth.

3 Stepan and Skach, supra note 1.

${ }^{4}$ Proponents of semi-presidentialism have argued that this system is unique and that it is neither a mixed system nor a transition from one pure system to the other. Authors claim this system arises from constitutional engineering. See Pasquino, in Elgie 7-8 (1999).

${ }^{5}$ Giovanni Sartori, Comparative Constitutional Engineering, an Inquiry into Structures, Incentives and Outcomes (MacMillan Press Ltd., $2^{\text {nd }}$ ed., 1997).

${ }^{6}$ Juan J. Linz, Presidential or Parliamentary Democracy: Does it make a Difference?, in The FaILure 
systems embody the following characteristics: both the congress and the president are in power for a fixed term as the result of a direct (or direct-like) ${ }^{7}$ election and interaction between both branches is independent of the other (i.e., both have a popular mandate and neither the president can disband the congress nor can congress dismiss the president and his cabinet). ${ }^{8}$

The separation of powers is a result of the first characteristic. Because of this separation, the president is responsible and accountable for the executive branch, and has the power to appoint and dismiss his cabinet without the approval of congress (There are some exceptions as in the case of the United States where congress ratifies certain appointments). Lijphart ${ }^{9}$ defines this idea as a one-person executive in a presidential system. According to Linz, ${ }^{10}$ one of the drawbacks of this core characteristic of presidential system is what he calls the "winner takes all" factor. In other words, the president completely controls the executive branch and cabinet appointments, thus taking all while the losing candidate loses all. Przeworsky ${ }^{11}$ also argues in favor of Linz's argument, stating that presidential systems form a zero-sum game because a president is in a position to establish a government that does not include losers. Under this system, the losing candidate cannot even be part of government as he can in the case of the parliamentary system, in which the runner-up becomes the leader of the opposition. Thus, victory seems to be greater and defeat is also more pronounced in presidential systems whereas the rules of the parliamentary system multiplies the payoff and the loser is encouraged to remain active in the democratic game. Carpizo" dismisses the "winner takes all" argument because this position is largely unattainable in situations in which the president does not have the majority in one or both chambers. Furthermore, in response to those who say parliamentary systems are more stable, Carpizo counters that setting up government under a parliamentary system with several political parties requires forming coalitions that are not always stable. This in turn can bring about constant changes in the cabinet and thereby political instability. Along this same line, Cheibub et al. ${ }^{13}$ contend that when no party holds a congressional majority in a presidential system,

of Presidential Democracy 3-87 (Juan Linz and Arturo Valenzuela eds., John Hopkins University Press, 1994).

${ }^{7}$ In some cases (i.e. United States), the president can be selected by an electoral college.

${ }^{8}$ Some constitutions grant the congress the power of impeachment, although it is highly unlikely for a president to be convicted.

${ }^{9}$ Arend Lijphart, Presidentialism and Majoritarian Democracy: Theoretical Observations, in The Failure of Presidential Democracy, supra note 6, at 91-105.

${ }^{10}$ Linz, supra note 6.

11 Adam Przewoski, Democracy and the Market: Political and Economical Reforms in Eastern Europe and Latin America (Cambridge University Press)(1991).

12 Jorge Carpizo, México: ¿sistema presidencial o parlamentario?, 1 Cuestiones ConstitucionaLes. Revista Mexicana de Derecho Constitucional 49-84 (1999).

${ }^{13}$ Jose Cheibub \& Fernando Limongi, Democratic Institutions and Regime Survival: Parliamentary and Presidential Democracies Reconsidered, 5 Annual Review Of Political Science 151-179 (2002). 
coalition governments take shape more than half the time, and even more frequently if no single party holds more than a third of the seats in congress. Most democratic presidential systems have a system of checks and balances since each branch has its own source of authority as well as an independent mandate from the people. This characteristic points at a second drawback of presidential systems, something Linz ${ }^{14}$ calls "dual democratic legitimacy." This means that both the congress and the president can claim democratic legitimacy, although the latter's is often considered more encompassing since congress only represents part of the population ${ }^{15}$ while the president represents the country as a whole. Regardless of which branch claims to have more legitimate power, checks and balances can minimize or even eliminate the "winner takes all" effect, especially in the case of a divided congress. Checks and balances may differ de facto and de jure and in certain circumstances, e.g, when the president's party holds the majority in congress, the president tends to dominate the legislative branch as well.

$\operatorname{Linz}^{16}$ also asserts that presidential regimes are rather rigid compared to parliamentary systems when dealing with a possible change in power if the president fails to deliver or has lost the confidence of congress or his own party. In the presidential system, the president is elected for a fixed term and will stay in power until the end of that term; whereas in the parliamentary system, if a prime minister has lost the confidence of parliament, it is highly unlikely he will remain in power. For the sake of argument, let us say that Linz's argument presupposes a president who begins his term with his party's confidence and that congress gives him the benefit of the doubt before losing the support of one or both. In this case, Linz's concern can even be taken a step further to illustrate a situation in which the president never actually obtained the confidence of congress. Presidential systems with many political parties participating in elections have shown that a president can be elected with low percentages of popular support. Moreover, the support a president receives in a general election can significantly differ from that of congress since voters may cast votes for candidates from different parties. Even more worrisome is the fact that after a controversial election, a president can assume power under polarized circumstances that stem from low legitimacy levels.

Proponents of presidentialism claim that "accountability" is a strong point in favor of these systems. ${ }^{17}$ Since citizens directly elect their president, they know exactly who they voted for, who they granted the power to govern to and who is responsible for government. In contrast, voters in parliamentary systems do not actually know beforehand what parties will be part of the governing coalition or who their leader will be, especially under minority governments. Thus, in terms of accountability, parliamentary systems spread

\footnotetext{
14 Linz, supra note 6.

${ }^{15}$ Either a constituency, a state (under federal systems), or both (under bi-cameral systems).

${ }^{16}$ Linz, supra note 6.

${ }^{17} I d$.
} 
the responsibility among the prime minister, the cabinet and the parliament, whereas in presidential regimes, responsibility is easy to attach to the president. Linz's criticizes presidential systems that do not allow the president to run for re-election because in his view, "a president who can not be re-elected is unaccountable." ${ }^{\prime 18}$ Furthermore, it can be said that the diffusion of sharing responsibility is even greater in presidential systems than in parliamentary regimes since the president can "accuse" congress of not letting him govern properly and pursue his agenda because congress blocks the required reforms.

So far, the discussion about presidential regimes has been addressed from the executive's standpoint, as it is in most literature. However, congresses in presidential systems have been claiming a more preponderant role in the public sphere as a collegiate policy maker. Most policies targeting the society are currently entitled by a piece of legislation or a congressional act. The budget cycle is a clear example of enhanced legislative power over the policy-making process and increased control over checks and balances since congress has taken on a more effective role in all the stages of the process: preparation, approval, execution, and accountability/review. Moreover, in budget execution, congress has gained more power over government expenditure policies by regulating social programs and grounding them in law. For instance, in the United States, only about one third of all federal spending is controlled in the annual appropriation process while spending for entitlement programs is determined by their enabling laws. ${ }^{19}$ These laws impose a significant constraint on government policy-making. In order execute his agenda, the president needs to act and cooperate with congress. On the flipside, Carpizo ${ }^{20}$ stresses $^{-}$ that under the traditional parliamentary system, namely the British one, if a single party attains the majority in the House of Commons, the leader of the winning party becomes prime minister and controls the parliament. Therefore, the legislative branch exerts no control whatsoever over the executive branch due to both party discipline and the fact that most MPs do not want anticipated elections.

If we agree that, in theory, presidential systems are more difficult to successfully perform because of core institutional arrangements, several questions should be considered: Is presidentialism incapable of delivering? Is there a way to improve a presidential regime? Some scholars (e.g., Linz) argue that the answer to a presidential system's problems lies in its evolution to a parliamentary system, while others (e.g., Sartori) $)^{21}$ propose a "less drastic" change (in terms of constitutional engineering) to a semi-presidential or "alternating presidentialism" system. In this article, I will argue that Sartori's view is probably more appealing in the case of Mexico. In the next section,

\footnotetext{
${ }^{18} I d$.

${ }^{19}$ Ian Lienert and Moo-Kyung Jung, The Legal Framework for Budget Systems, 4 (3) OECD Journal on Budgeting 1, 1-483 (2004).

${ }^{20}$ Carpizo, supra note 12 .

${ }^{21}$ Sartori, supra note 5.
} 
I will briefly describe the structure of the Mexican system before going on to present my proposals to reform key institutional arrangements.

\section{Transition to Democracy: Evolution of Institutional Arrangements and the Balance of Power}

Since its independence the history of Mexico has been characterized by an unstable political order and a long list of "monarchs" and "warlords." However, Mexico is different from other Latin American histories in that it has never been under military dictatorship. Mexican regimes may have been rather authoritarian — led by a man with either a military or civil background - but political institutions have never been subjected to military rule. Although Mexico did hold regular elections, they was dominated by a single party in power for more than six decades because of the following mechanisms: a) an all-powerful president who, according to some scholars, had both constitutional and "meta-constitutional" powers (see Meyer, 1993; Carpizo and Cordova, 1985); and b) frequently changing electoral rules, which helped exert control over congress. Using Merkel's ${ }^{22}$ theoretical concept of democracy, these circumstances fit perfectly into one of his four types of "defective democracies:" delegative democracy. ${ }^{23}$

It is necessary to know several key historical facts to understand the current institutional arrangements in the Mexican presidential system and the evolution of the balance of power among institutions over the last two decades. This section will cover these facts, though the following description is not intended to be a comprehensive review of Mexican history; rather, it is a somewhat subjective overview of historical episodes that help understand how the system is conformed.

\section{Post-Revolutionary Period: Conformation of Presidential Power}

As a result of President Santa Ana's eleven terms in office and Porfirio Díaz's three decades in power during the so-called "Porfiriato," one of the

\footnotetext{
${ }^{22}$ Wolfgang Merkel, Embedded and Defective Democracies, 11 (5) Democratization 33-58 (2004).

${ }^{23}$ Merkel's theory of democracy is based on the argument that the term "electoral democracy" is normative and theoretically inadequate to define whether a country can be classified as democratic or not - as it only takes into account the existence of free and fair elections. He states that for a country to be classified as democratic, it must fulfill at least five main features internally and three features externally. If the country meets all these criteria, it can be classified as an "embedded democracy," whereas if the country fails to comply with even one of them, it should be considered a 'defective democracy', divided into four types of such democracies eg. exclusive, domain, illiberal and deelegative democracies.Merkels' definition of a "delegative democracy" is a system characterized by a weak legislature and judiciary, in which these two branches only have limited control over the executive branch and the president can circumvent the parliament and influence the judiciary.
} 
principal demands of the 1910 revolution was that of banning presidential re-election. Porfirio Díaz's long period in power was to a large extent possible due to his restrictive policies of sharing and distributing the economic benefits with a small elite group of politicians, businessmen, bankers and landowners. By distributing the rents of the economic growth among these key groups, Díaz secured his permanence in power. However, the same policy that kept him in power was also responsible for his exile. Large groups of peasants and a growing working class, who were earning no rent from these elitist policies, organized and started to mobilize themselves and attack the government, demanding equal privileges for all. After Díaz's exile, his successors, first Madero and then Huerta, tried to address the demands of the newly organized groups, particularly the small farmers via a land reform that aimed at significantly redistributing land. However, an unstable environment and the inability to deliver on the promises resulted in Madero's assassination while Huerta was overthrown and exiled. As a result, two revolutionary movements emerged: the constitutionalists, led by Carranza; and the anticonstitutionalists, divided into two different groups in northern and southern Mexico led by Villa and Zapata, respectively. Carranza defeated these groups and garnered support by "forging alliances with groups that were committed to far-reaching social reforms." ${ }^{\text {24 }}$ Consequently, the 1917 Constitution (which is still in effect) was comprehensive in terms of including several of the new stakeholders, such as peasants, the working class, and businessmen. However, in terms of institutional arrangements, the text of the constitution enhanced the president's powers and placed him in a higher position than congress.

The same practices of patronage and rent distribution remained in place during the subsequent presidencies of Obregon (1920-1924) and Calles (1924-1928). However, in terms of political organization, by the end of the 1920 s, around 150 parties had emerged, each demanding a share of the rents and insisting the revolution benefit them too. Obregon was reelected in 1928 - against the revolutionary demand of no re-election - thanks to a reform Calles carried out by convincing the congress to amend the constitution so as to allow reelection for non-consecutive terms. Obregon was then assassinated which resulted in Calles' reemerging as the strongest political figure in the country. President Calles was aware that the history of warlords and monarchs was still fresh in people's minds. Thus, instead of following Obregon's path, Calles decided to become the man behind the power and establish what is known in Mexico's history as the "Maximato." ${ }^{25}$ Calles appointed the next three Mexican presidents who were each under his command.

Calles knew the benefits of patronage politics and as an experienced leader who was well versed in forming coalitions, he unified most of the 150 par-

${ }^{24}$ Stephen H. Haber et al., Mexico Since 1980 (Cambridge University Press, 2008).

${ }^{25}$ The Maximato is the period between 1928 and 1934. This period was characterized by a very strong leadership in the figure of Calles, who was called "El jefe máximo de la Revolución" (the supreme leader of the revolution). 
ties into a single party, the PNR (which is now known as the PRI) by creating a common ground to deliberate on and solve the ever-increasing demands. This unification was made possible by creating a de facto single-party system with a single figure as its head. Calles' last appointee in 1934 was President Lázaro Cardenas, who turned out to be a drawback for "el jefe." Even though Cardenas concurred with the idea of maintaining a single figure at the head of the party and the government, he believed this figure ought to be the incumbent president. Since Cardenas's presidency, some of the practices established within the single party in power became practically institutionalized within the PNR party. These practices, or more precisely meta-constitutional powers, include: presidential appointment of the president's successor (as well as appointing governors and candidates for both chambers) and absolute control of the official (PNR) party. Both of these practices were in place until the end of the 20th century. "Until the 1990s, the PRI held an effective monopoly on the exercise of the political power. Indeed, the line between the party and the government blurred to the point that they were often viewed as one and the same." ${ }^{26}$

Thus, President Cardenas severed the bond with the long history of longterm presidents and weak presidents, who sometimes remained in power for even less than a year, in a politically unstable environment emanating from pre- or post-revolutionary processes. Cárdenas legitimized and enhanced the power in hands of the president as Meyer $^{27}$ describes in the following lines: "[t] he presidential power under the new Mexican regime was only consolidated since General Lázaro Cárdenas (1934-1940). Then and only then, could the president have absolute constitutional and meta-constitutional powers. ${ }^{{ }^{2} 8}$ Some of the meta-constitutional powers Meyer refer to are: control over institutions, courts, local governments, congress, mass media and even some of the minor political parties. Cardenas did impose one limit on these powers, namely a term limit, which he respected at the end of his mandate.

The same presidential powers were transferred from president to president over the following 60 years under the shelter of same party. ${ }^{29}$ Some questions that arise at this point are: How did the PRI manage to keep their power so effectively? If the PRI was so powerful, what caused its defeat? The following section will attempt at answering both of these questions.

\section{Role of Parties and Congress in the Process of Democratization}

The "official" party (PRI) continued to grow over the following years to gradually include a wider range of social sectors. In 1938, the party had

\footnotetext{
${ }^{26}$ Haber, supra note 24.

${ }^{27}$ Lorenzo Meyer, El presidencialismo: del populismo al neoliberalismo, 55 (2) Revista Mexicana DE Sociología 57, 57-81 (1993).

${ }^{28}$ My translation of Meyer, supra note 27.

${ }^{29}$ The PNR became the PRM in 1938 and finally the PRI in 1946.
} 
already built up strong bases in the working class, peasants the armed forces and many social organizations. Scholars track the creation of corporatism in Mexico to this particular point in time. Corporatism was the main way of controlling and keeping power primarily through co-optation and repression. Over the following decades, the system ran smoothly not only because of the president's and the "official" party's absolute power, but also due to sustained economic growth attributed to the import substitution model. Between 1954 and 1970, the GDP grew at an average rate of $6.7 \%$ a year. ${ }^{30}$

With such overwhelming power over political institutions and social sectors, how can the downturn of the PRI's monopoly of power be explained? Three primary factors that had an impact on the PRI's political hegemony can be attributed to the party's decline: (1) the student mobilization in the late 1960s; (2) the economic shocks of the late 1970s and early 1980s; and (3) the electoral reforms (in response to a growing opposition and a greater need for legitimization).

The 1968 student mobilization — which was brutaly repressed - took place on the verge of the Olympic Games in Mexico. This public mass repression had a significant impact on the official party hegemony. These events made the population aware of the limits of the power exerted by the "authoritarian regime" (or their absence). The social movement did not only include riots and social protests, but also brought in more participation from the intellectual sector as more and more scholars began to oppose the regime.

The economic shocks in the late 70 s and early 80 s also had a major impact on the political support of the official regime. During this period, the import substitution model and state-led industrialization proved to be deficient. According to Meyer, ${ }^{31}$ the problem can be traced back to the need for investing in the inefficient industrial sector, which was incapable to export its goods. Hence, the government's response to this was to go into external debt. This was possible through readily available private loans, as well as resources offered at that time by international financial institutions. Pastor ${ }^{32}$ asserts that in the 1970s, the International Monetary Fund relaxed the conditions to access funds. Due to these developments, by the second half of the 70s, the Mexican economy had blatant over-borrowing, inflation $(27 \%)$ and a significant devaluation of its currency $(76 \%)$ in 1976 . The change in government the same year was blessed by the 1977 discovery of "Cantarell" — an important oil reservoir. High international oil prices raised government expectations and so it continued to borrow - using oil as collateral - and spend even more over the following years. However, in 1982, a sudden drop in oil prices left the indebted Mexican government in one of the worst economic crises in its his-

\footnotetext{
${ }^{30}$ Source: INEGI [National Institute of Statistics and Geography], Banco de Información Económica [Economics Information Bank].

31 Meyer, supra note 27.

32 Manuel Pastor, Latin America, the Debt Crisis, and the International Monetary Fund, 16 (1) LaTiN American Perspective 79-110 (1989).
} 
tory, leading the country to default on its external debt. Thus, the absence of rents to distribute and the extreme impact it had on all sectors of the society eroded popular support for the PRI.

As a change in power was virtually unthinkable, the only possible way the opposition could start incrementally gaining ground in the political arena was through congress. Since its founding in 1939, the PAN (Partido Acción $\mathrm{Na}$ cional) has been the main opposition to the PRI. "In the 50s and 60s, with a distinctive ideology and opposite to that of the Mexican Revolution, the PAN obtained visibility and public adepts. However, over that period, its role was merely testimonial. ${ }^{{ }_{33}}$

Although underrepresented in congress, the PAN started to change the dynamics of the political scene. The PRI instituted certain electoral reforms in the $30 \mathrm{~s}, 40 \mathrm{~s}$ and $50 \mathrm{~s}$ to enhance presidential control over institutions. These moves alienated the opposition, who, in a strategy that paid off, decided to stop playing the "democratic" game by not proposing presidential candidates and refusing to take the seats won in congress. Hence, the PRI party - always concerned with maintaining the formalities of the democratic game- had to make sure of keeping up appearances. In response, the government offered political liberalization in exchange for the continued participation of opposition parties in the electoral arena. ${ }^{34}$

In the early $60 \mathrm{~s}$, the race towards a more democratic system began. However, the dominant party intended to maintain its hegemony and so passed a reform in 1962 to introduce the so called "diputados de partido" [party deputies], which was a form of proportional representation (PR) to ensure the participation of other parties. As summarized by Molinar Horcasitas et al.: ${ }^{35}$

The party deputy system was a two-tier system, with linkage between the tiers to limit the number of seats that a party could win from the list tier [...] The nominal tier included 178 seats in SSDs [single seats districts], chosen by plurality in which any party could compete. The list tier was reserved for minority parties, defined as parties with $2.5 \%$ or more of the national vote, but which had won fewer than twenty SSDs [...] parties were entitled to five seats if they reach the legal threshold of $2.5 \%$ of the national vote; then they received one seat for each $0.5 \%[\ldots]$.

Since the PRI party was confident of its absolute dominance over SSDs, it created the incentives for minority parties to join the democratic game. However, the system established clearly favored minority parties at the expense of

\footnotetext{
${ }^{33}$ José Woldenberg, Estados y partidos: una periodizacion, 55 (2) Revista Mexicana de SociOLOGíA 83-95 (1993).

${ }^{34}$ Juan Molinar Horcacitas \& Jeffrey Weldon, Reforming Electoral Systems in Mexico in Mixed-Member Electoral Systems - The Best Of Both Worlds? 209-230 (Matthew S. Shugart \& Martin P. Wattenberg eds., Oxford University Press, 2003).

${ }^{35} I d$.
} 
the PAN. In 1977, the "diputado de partido" system was abandoned in favor of an actual mixed system. The seats in the chamber of deputies/congress were increased to 300 for SSDs and 100 for multi-seat districts (MSDs), which were assigned according to each party's lists. Further reforms were carried out by the ruling party, but now with some negotiation with the opposition. One outcome of these bargaining processes was the 1986 electoral law. Electoral reforms evolved in such a way that delayed the democratization process as they created a rather divided opposition that competed against each other for seats in congress rather than joining forces to overthrow the PRI. Eventually, though, electoral competition arrived.

According to some scholars, the 1988 election under the new law marked the opening to political competition. The PRI faced two strong opposition parties, the historically second strongest party, the PAN, and a coalition of left-wing parties supporting a candidate of the PRD party founded by former PRI members. The PRI was declared the winner with $50.74 \%$ of the votes. This was the lowest number of votes received by the incumbent party in its history. And, for the first time ever, the PRI lost its qualified majority in the chamber of deputies required to make constitutional reforms. For Molinar Horcasitas et al. ${ }^{36}$ this moment in time marked the evolution of politics in Mexico and shifted the debate towards political liberalization.

\section{Electoral Reforms of the 1990s and the Subsequent Balance of Power}

Since the 1988 results, further reforms were introduced to the federal electoral law with each party pulling in a different direction. The PRI wanted to restore its former hegemonic position while the opposition parties led by the PAN and the PRD wanted to create a more independent electoral body. In the negotiation process, the PAN accepted a reform which largely benefited the PRI in 1991. However, PAN had two different goals: first, to ensure that winners - of federal states governorships - would be recongnized as such; and second, to make the electoral body more independent. These efforts brought about the creation of the Federal Electoral Institute (IFE), which in 1996 became completely independent.

The 1996 reform and the enactment of the COFIPE $^{37}$ (Federal Code for Institutions and Electoral Procedures) were designed to guarantee a fair process and reassert the importance of political parties. Although there has been a series of further reforms to the COFIPE, the voting system used for seats in congress has remained the same, a mixed system with 300 SSDs and 200

\footnotetext{
${ }^{36} I d$.

${ }^{37}$ Código Federal de Insituciones y Procedimientos Electorales [C.O.F.I.P.E.] [Federal Code for Electoral Institutions and Procedures], Diario Oficial de la Federación [D.O.] 1996 (Mex.).
} 
MSDs. ${ }^{38}$ The threshold for PR seats was increased to $2 \%$ of the national vote and the cap for overrepresentation was set at $8 \%$.

The results of Chamber of Deputies elections between 1988 and 2009 in Table 1 below clearly show that since 1988 congress has been characterized by the absence of a majority (except in the $55^{\text {th }}$ legislature) and a clear multi-party system with three main parties and some minor parties. Thus, the presidential regime a single party in power and controlling the Chamber of Deputies was no longer in place. Therefore, any president who wanted to carry out a specific agenda would now have to seek support from one or two of the opposition parties.

\section{Table 1. Gonformation of the Chamber of Deputies BY LEgisLature 1988-2009}

\begin{tabular}{|l|c|c|c|c|c|c|c|c|}
\hline & LIV & LV & LVI & LVII & LVIII & LIX & LX & LXI \\
\hline Party & $1988-1991$ & $1991-1994$ & $1994-1997$ & $1997-2000$ & $2000-2003$ & $2003-2006$ & $2006-2009$ & $2009-2012$ \\
\hline PAN & 101 & 89 & 119 & 121 & 213 & 151 & 206 & 143 \\
\hline PRI & 262 & 320 & 300 & 239 & 211 & 224 & 104 & 237 \\
\hline PRD & & 41 & 71 & 125 & 51 & 97 & 126 & 71 \\
\hline PT & & & 10 & 7 & 6 & 6 & 16 & 13 \\
\hline PVEM & & & & 8 & 11 & 17 & 19 & 21 \\
\hline Others & $137 *$ & 50 & & & 8 & 5 & 29 & 15 \\
\hline & & & & & & & & 500 \\
\hline Total & 500 & 500 & 500 & 500 & 500 & 500 & 500 \\
\hline
\end{tabular}

* Others in 1988 stands for the Frente Democrático Nacional, a big coalition of left parties which was disolved after the instalation of the chamber.

SOURCES: Instituto Federal Electoral, www.ife.org.mx; and for 1988 Cámara de Diputados, www.cddhcu. gob.mx.

The main goal of the electoral reforms of the 1990s was to create a clear, fair and trustworthy legal framework that coincided with the new conditions of plurality and competition. The creation of the IFE and the Federal Electoral Court (TEPJF $)^{39}$ was key in achieving the results shown in Table 1. This influence was not just due to their establishing clearer electoral processes, but also their sanctioning and legitimizing election results.

After the results of the Chamber of Deputies elections, presidential power eroded to the point of implosion. The PRI was no longer capable of main-

${ }^{38}$ Composition of the chamber was enlarged from 400 to 500 (100 more MSDs) in a reform carried out in 1986.

${ }^{39}$ Tribunal Electoral del Poder Judicial de la Federación [T.E.P.J.F] [Federal Electoral Court]. 
taining hegemonic power over institutions. The 1994 election results were proof of a plural population. Though the PRI won the presidential seat, the PAN party consolidated itself as the PRI's main opposition, and PRD remained as a third rival (see Table 2). The scenario changed in 2000 when the PAN presidential candidate won the election. These results were unequivocally a show of citizens' commitment to the transition to democracy. The change of power was effected through the so called "voto util," which meant that people basically cast their votes for the candidate with more probability of winning against the PRI. People also used their prerogative for a "split vote" by then voting for their preferred party for seats in congress.

\section{Table 2. Presidential Election Results}

(1994-2006)

\begin{tabular}{|l|c|c|c|}
\hline \multicolumn{4}{|c|}{ Presidential Elections } \\
\hline \multicolumn{1}{|c|}{ Party } & $1994-2000$ & $2000-2006$ & $2006-2012$ \\
\hline PAN & 25.92 & 43.40 & 35.89 \\
\hline PRI & 48.69 & 36.80 & 22.26 \\
\hline PRD & 16.59 & 17.00 & 35.31 \\
\hline Turnout & 77.16 & 63.97 & 58.55 \\
\hline
\end{tabular}

SOURCE: IFE, www.ife.org.mx.

The scenario changed again in 2006 in what has been considered the narrowest and most contentious election ever. This time the PRI dropped to the third place - going from $48 \%$ of total votes in 1994 to $22 \%$ in 2006 . In my opinion, this suggests that the "voto útil" was used once again as the two parties at the "extremes" of the political spectrum fought for the presidential seat. After much deliberation, the TEPJF declared PAN candidate Felipe Calderón by a difference of just $0.58 \%$. This decision was received with a series of riots and other forms of public protest, particularly in Mexico City, for almost a year. In such an extremely polarized political situation, Congress also showed signs of division.

Hence, for almost 20 years now, ${ }^{40}$ citizens have opted to choose their leaders and representatives from different parties, reflecting the country's transition from a somewhat authoritarian regime with a hegemonic party in power to an electoral democracy. ${ }^{41}$

${ }^{40}$ These 20 years span from 1994 to 2012 since the elections to replace the members of Congress who were elected in 2009 will be held in 2012.

${ }^{41}$ Although I agree with Merkel's sound and solid new theory on the analysis of democracy, the merits of the somewhat contentious and imperfect the term "electoral democracy" is beyond the scope of this paper. 
Among the many problems new regimes have to face, there is a lack of coordination and cooperation between the executive and legislative branches. This often leads to legislative gridlock, particularly when dealing with "structural reforms" that aim at significantly reforming the constitution or federal laws.

\section{Remaining Threats to Mexican Presidentialism: \\ A Proposal to Enhance the System}

However, there are still potential threats to presidentialism Characterized by Sartori as "genius" and "unique," ${ }^{42}$ Mexican presidentialism has consistently adjusted its institutional arrangements to ensure that the system will continue to work: the "winner-takes-all" situation from an executive perspective, and few inducements to engage in cooperative games with the executive, from a legislative standpoint. Thus, legislative gridlock is still a possibility that can hamper attempts to bring about the presidential agenda, as is poor performance resulting in less political stability.

This final section is divided into two sections: the first section addresses the institutional arrangements that can increase the risk of political instability and poor performance from both executive and legislative perspectives; the second section briefly proposes a possible course of action to enhance the institutional arrangements needed to foster cooperation and encourage good performance.

\section{Remaining Threats to Democracy in Mexico}

As Carrillo and Lujambio ${ }^{43}$ have pointed out, unusual situations call for greater cooperation/more negotiation among political parties, which in fact entails a new institutional learning process for the polity. ${ }^{44}$ Thus, the new balance of power has presented the Mexican system with the new challenge of engaging in cooperative games with the opposition and institutions. In my opinion, the lack of cooperation between the executive and legislative branches, especially in the current administration, has augmented possibility of legislative gridlock. Although the polity has shown maturity in the effective separation of powers environment, the institutional arrangements and the electoral results opened the door for such pitfalls.

${ }^{42}$ ESPIRAL: Interview with Giovanni Sartori (Oct. 11, 2009).

43 Ulises Carrillo \& Alonso Lujambio, La incertidumbre constitucional. Gobierno dividido y aprobación presupuestal en la LVII Legislatura del Congreso mexicano, 1997-2000, 60 (2) Revista Mexicana DE Sociología 239-263 (1998).

${ }^{44} I d$. 
In its bicameral legislative system, the Mexican Constitution gives both chambers and the president the power to present initiatives on almost all matters. ${ }^{45}$ The chambers ${ }^{46}$ have to approve all initiatives by absolute majority, unless a two-thirds vote has been established in the constitution. Upon its approval in congress, the bill is sent to the executive, who in the absence of comments will officially publish the bill which at the moment of publication becomes a law. The Constitution also establishes a president's power of veto, which congress can only override with two-thirds in both chambers. Only then will the bill become a law.

With these institutional arrangements and the distribution of seats in congress shown in Table 1 since the 2000 and 2006 presidential elections, the possibility of legislative gridlock has been present: the president's party (PAN) did not have the majority, controlling 213/500 and 206/500 seats, respectively. Thus, simple math shows that neither could the president pass legislation without a legislative coalition, nor could the opposition in congress override a presidential veto. After the 2003 and 2009 mid-term elections the conformation of congress changed, leaving the PAN with less than one third of seats and the president in an extremely weak position with no legislative power whatsoever.

As Barracca pointed out, ${ }^{47}$ President Fox "experienced the frustrations of trying to rule with a divided government" as he failed to pass important and polemical pieces of legislation, which were blocked by the PRI and the PRD. When President Calderón took office, he showed more sensibility in the bargaining process by negotiating with the opposition in congress mainly with the PRI - to approve a tax reform at the end of 2006. In 2008, President Calderon embarked on a major reform in the energy sector, the same one former President Fox had attempted to pass when in office, and succeeded. However, the reform was diluted to such an extent that President Fox considered it a Pyrrhic victory in view of what had originally been sent to congress.

The separation of powers and the shift of power towards congress - due to the distribution of a similar number of seats among the three main parties - have changed the Mexican hyper-presidential system to one with a strong separation of powers. Furthermore, the plurality rule for electing the president under the $3+$ effective parties system has caused an even split of the votes for the main parties' candidates (one third of the votes for each party).

\footnotetext{
${ }^{45}$ Some exceptions are the Revenues Law and the Budget decree in which the lower chamber has the prerogative of initiating the process and the upper chamber (Senate) is responsible for its review.

${ }^{46}$ One exception is the ratification of international treaties, which only need to be approved by the Senate.

${ }^{47}$ Steven Barracca, Is Mexican Democracy Consolidated?, 25 (8) ThIRD World Quarterly 1469-1485 (2004).
} 
Thus, as seen in the 2006 presidential election, the difference between the runner-up and the winner can be as little as less than one percentage point. Why can strong separation of powers and close electoral competitions be such an aberrant arrangement?

The fact that the president has to make an effort in bargaining to pass legislation should not be a problem; it is in fact a feature of the separation of powers that is intended to generate more measured policies. As stressed by Mainwaring et al. ${ }^{48}$ party discipline makes it easier for the president to negotiate with party leaders, rather than having to negotiate with individual MCs, thus simplifying the process. However, Cheibub ${ }^{49}$ asserts that disciplined parties can hinder the president's ability to form a coalition to approve specific legislation, as in the case of Mexico. Mexico's specific institutional engineering can turn this apparently positive effect into something negative. The combination of strong partisanship with the absence of reelection creates a system in which MCs prefer to follow the party line than that of citizens since MCs cannot be punished with not being reelected by voters, but can be penalized with not being promoted to higher positions by their party leader.

To better illustrate the high level of party discipline in Mexico, I have developed a simple index which, although imperfect, gives a sense of how disciplined parties are when voting on important reforms. The index is based on the following:

- I collected a data set with information on all the votes cast for each constitutional reform between 1998 and 2010 and divided it by legislature;

- The total votes were classified by party (the three main parties plus one of the minor parties, the PVEM $)^{50}$ and the way each party member cast his or her vote (for, against or abstention) was further analyzed;

- The simple formula $\mathrm{PD}_{\mathrm{i}}=\mathrm{Mv}^{*} 100 / \mathrm{Tv}$ was applied to this information with $\mathrm{PD}_{\mathrm{i}}$ standing for Party Discipline of Party i; Mv, for the majority of party members voting the same way; and $\mathrm{T} v$, for the total number of votes that party emitted.

- Finally, all the Legislatures were then added to obtain an average for each party.

${ }^{48}$ Scot Mainwaring et al., Presidentialism and Democracy: A Critical Appraisal, 29 (4) Comparative Politics 449-47 1 (1997).

${ }^{49}$ José A. Cheibub, Minority Governments, Deadlock Situations, and the Survival of Presidential Democracies, 53 (3) Comparative Political Studies 284-312 (2002).

${ }^{50}$ I make special mention of the PVEM because it is a party that has consistently met the $2 \%$ threshold and by a significant margin (7-8\%). Moreover, since 2000, it has established electoral coalitions with both major parties, the PAN and the PRI. 
Table 3. Index of Party Discipline

Party Discipline (1997-2010)

\begin{tabular}{|l|c|c|c|c|c|}
\hline Legislature & PRI & PAN & PRD & PVEM & No Reforms $^{\circ}$ \\
\hline LVII & 99.6 & 89.4 & 94.1 & 100 & 22 \\
\hline LVIII & 91.7 & 98.1 & 99.7 & 95.5 & 8 \\
\hline LIX & 97.8 & 99.6 & 98.2 & 99.4 & 25 \\
\hline LX & 95.6 & 99.0 & 91.7 & 99.2 & 25 \\
\hline LXI & 100 & 95.4 & 100 & 97.3 & 2 \\
\hline Index 0-100* & 96.95 & 96.29 & 96.76 & 98.30 & 82 \\
\hline
\end{tabular}

* Where 0 is no discipline and 100 is full discipline.

Source: data from Cámara de Diputados, www.cddhcu.gob.mx.

As seen in the results in Table 3, the voting tendencies of each party have been consistent in five legislatures. Taking a closer look, the PAN was the least disciplined party during the $57^{\text {th }}$ Legislature when it was part of the opposition, but that once in power (from $58^{\text {th }}$ Legislature onwards), party discipline increased significantly. The PRI party had almost $99.6 \%$ of party discipline when it was last in power, but it became an opposition party, discipline dropped to $91 \%$.

Unlike Lijphart's ${ }^{51}$ assertion that presidential systems discourage multipartyism and cohesive parties, as shown in Table 3, the Mexican case is different: parties are the only institutions that can promote candidates for public office, and so party cohesion is strong. In fact, members who do not align themselves with party leadership are dismissed or tend to withdraw from the party to join or found a different party (as in the case of the schism in the PRI, which led to the creation of the PRD).

Incentives for MCs are set up so that MCs clearly align themselves with party leadership. Therefore, if we assume that parties' main concerns - especially for the opposition - is to have access to power (whether executive or legislative) and a successful government increases the odds of remaining in power, opposition party leaders will not engage in cooperative games, MCs will tend to become office-seekers, and citizens will be left out of the equation. Likewise, under such circumstances, as Carrillo et al. pointed out, ${ }^{52}$ the opposition has no incentives to cooperate: if they do with successful results, the president will take all the credit, increasing his chances (or those of his party) of staying in power, but if the opposite occurs, all the members of the opposition will share in the failure.

Further concern is presented by the number of "effective parties" in the Mexican presidential system. According to Weldon, ${ }^{53}$ the effective number of

\footnotetext{
51 Lijphart, supra note 9.

${ }^{52}$ Carrillo et al., supra note 43.

53 Jefrrey A. Weldon, The Consequences of Mexico's Mixed-Member Electoral System, 1988-1997,
} 
parties (Nv) in Mexico has increased with each electoral reform from 1988 to 1997, culminating in an $N v$ of 3.42 in 1997, a figure that has remained almost the same. This is partially due to the fact that low $2 \%$ threshold required to remain in the democratic game has created an array of parties coming in and out of the game over the years. Thus, the PAN, the PRI, and the PRD can be considered the three $\mathcal{N}$. The PVEM, a party that has consistently appeared on the ballots since 1997 and increased its number of seats by forging alliances with one of the three main parties, still lags behind the three major parties. For the sake of simplicity, I will only take into account the $\mathcal{N}_{v}=3$.

Statistical analysis in Cheibub's work (2002), as well as his argument, suggests that the effective number of political parties increases the likelihood of a minority government. However, the author asserts that it is not the $\mathcal{N} v$ that affects presidential systems in terms of the survival of the regime, but rather circumstances of very low pluralism. This opinion is shared by Sartori, ${ }^{54}$ in what he calls "moderate pluralism," which "encompasses between three and five relevant parties."

For Cheibub, ${ }^{55}$ it is not the existence of $<3 \mathcal{N v}_{v}<5$ that is the problem per se, but rather the distribution of power (number of seats shared) among these parties, which can lead to a break down in the system since each party will try to put forward its preferred policy. Furthermore, he stresses, any coalitions created within this context would be unstable. To prove that cases in which $<3$ Nv $<5$ are more likely to generate an even distribution of seats, he develops the "index of equiproportionality" from the total number of seats held by the three major parties weighed against the number of seats held by the largest party. In his own words: ${ }^{56}$

This last measure is an index of equiproportionality among the three largest parties, at least in the range of cases in which the largest party gets more than $30 \%$ of the votes. In this range, the closer this number is to 1 , the more concentrated is the distribution of strength among the three largest parties; the closer it is to 3 , the more evenly divided are the seats held by the three largest parties.

Replicating the index to reflect the recent composition of the Mexican congress since the alternation in power confirms Cheibub's assertion. Table 4 shows that in three out of four elections, the index was above 2.10 whereas only in one (2009), it was 1.90, which is still relatively high. It should be noted that the index of equiproportionality decreases in mid-term elections (when only the lower chamber is elected), but in presidential elections, the president's party usually emerges as the strongest.

in Mixed-Member Electoral Systems - The Best of Both Worlds?, supra note 34, at 447476.

${ }^{54}$ Giovanni Sartori, Parties and Party Systems: A Framework for Analysis (Cambridge University Press, 1976).

${ }^{55}$ Cheibub, supra note 49.

${ }^{56}$ Id. 


\section{TABle 4. IndeX of EQUiproportionality By Election (2000-2006)*}

\begin{tabular}{|l|c|c|c|c|}
\hline & \multicolumn{2}{|c|}{ Presidential Election } & \multicolumn{2}{c|}{ Midterm Election } \\
\hline & 2000 & 2006 & 2003 & 2009 \\
\hline PAN & 213 & 206 & 151 & 143 \\
\hline PRI & 211 & 104 & 224 & 237 \\
\hline PRD & 51 & 126 & 97 & 71 \\
\hline Total & 475 & 436 & 472 & 451 \\
\hline \multicolumn{5}{|l|}{} \\
\hline Index 1-3 & 2.23 & 2.12 & 2.11 & 1.90 \\
\hline
\end{tabular}

* The table shows the number of MCs resulting from each election, not the final configuration of the chamber.

Hence, we can say that the Mexican system is one with $3+$ main parties with an even distribution of power in which coalitions - but not long-lasting ones - can be formed for specific initiatives, making it possible for the opposition to blackmail the president's party. This encumbers the president's capacity for implementing his agenda, or at least the cost increases when it needs to go through congress, and therefore can lead to poor government performance if the president does not meet the demands of the opposition.

\section{Enhancing the Mexican Presidential System}

Throughout this article I have attempted to depict a somewhat clear, though not complete, picture of the Mexican presidential system since its creation and the rationale of its composition as it stands today. Presidentialism in Mexico has evolved in two different directions: 1) as a strategic response from the incumbent party to growing pressure from the opposition, which consisted of reforming the electoral system in such a way that discouraged collaboration among opposition parties and reinforced the hegemony of the party in power; ${ }^{57}$ and 2) as an array of somewhat collaborative efforts made by the three main parties to promote more equal competition, independent electoral institutions and fair and democratic elections.

However, as shown above, some threats persist: (i) low levels of legitimacy for the executive branch, (ii) party-oriented and office-seeking legislators; and (iii) a lack of cooperation. As a result, there is much need for improvement. The final section of this article presents some reforms that can be made to

${ }^{57}$ Alberto Díaz-Cayeros \& Beatriz Magaloni, Mexico: Designing Electoral Rules by a Dominant Party, in Handbook of Electoral System Choice 145-154 (Joseph Colomer ed., Palgrave Macmillan, 2004). 
institutional arrangements to address each of the abovementioned threats and therefore enhance the Mexican presidential system.

\section{A. Endowing Legitimacy to the Executive Mandate}

The combination of plurality rule and three political parties with different positions on the political spectrum has brought the system to the precarious situation in which the president won the election by less than one percent. ${ }^{58}$ To solve this first problem, one proposal would be to change the current presidential election rules to a majority rule with a second-round runoff. This would legitimize the president without harming the plural nature of the system. As Colomer says, ${ }^{59}$

An electoral system based on the majority principle which tends to produce a single, absolute winner and subsequent absolute losers, must be considered a more risky choice [...] The corresponding results to be found in a long-term historical perspective should thus be increasing numbers and proportions of electoral system choices in favor of those formulas and procedures producing multiple winners, as well as a relative reduction of existing electoral systems producing a single absolute winner.

A second round runoff would give winners more legitimacy: if no candidate receives an absolute majority in the first round, the two candidates with the most votes will go on to a second round - forcing both candidates to forge a stable coalition.

Even though I believe this would be the best solution for Mexican presidentialism, some drawbacks of this system must be mentioned. A second round runoff can give rise to new political parties, either because they expect to reach the second round or simply because they want to be part of a winning coalition and thus have a stake - however minor - in government. Nevertheless, with this practice, small parties can come to blackmail parties that make it to the second round. To prevent a "flood" of small political parties, the minimum threshold to be considered a political party should be doubled from $2 \%$ to $4 \%$. A second caveat is related to turnout. A second round is likely to produce lower turnout, so if the system is already experiencing low levels of participation, the second round may not give a clear winner. To avoid such problems, the second round should coincide with legislative elections. Finally, a second round is perhaps more costly for citizens. Good cam-

${ }^{58}$ In 2006, the runner-up candidate from the PRD refused to recognize the results of the elections and challenged presidential authority, electoral institutions and the electoral body (IFE) itself. He began a show of "peaceful" resistance which lasted for almost a year.

${ }^{59}$ Joseph Colomer, The Strategy and History in Electoral System Choice, in Handbook of Electoral System Choice, supra note 57, at 3-80. 
paign regulations and caps on resource allocation can minimize this effect, but not entirely. I also believe the supplementary vote should be analyzed in more detail as it represents an option for an instant runoff system, which can help avoid a costly second round.

\section{B. Reorienting Legislators towards Their Constituencies}

The constitutional prohibition of immediate reelection for all elected offices is a threat that hinders a political system from performing effectively. As mentioned in the second section of this article, the ban on reelection was put forward at the time of the Mexican revolution and still has a negative connotation in people's minds. In terms of congress, consecutive reelection was abolished in 1933, perhaps as the executive branch's way of enhancing its power in response to a more assertive congress.

In congress, the division of labor generally leads its members to acquire a certain degree of specialization that can benefit an institution. By sharing activities, giving unequal influence in different areas to different members of the institution, incentives are created for members to get to know their areas, developing specialized knowledge and accumulating relevant current information..$^{60}$

In the absence of consecutive reelection, MGs have a three-year term limit which has several negative consequences: (i) it hampers their professionalization by not allowing them to advance in terms of a legislative career; (ii) it reduces their desire to engage in long-term policies (or projects); (iii) in most cases, it severs bonds with their constituencies from their very first day in office because MCs are not accountable to their constituents; (iv) their loyalties, as well as their interests, lie with the party; (v) the combination of points iii and iv transforms legislators into office-seekers; and (vi) a side effect is that it limits the possibility of carrying out civil service work with strong technical skills because senior staff is also constrained by the term limit.

Those defending the ban on consecutive reelection claim that the effects are not that negative since MCs can run for that same office again three years later. Furthermore, they point out, an MC can serve a 6-year term as Senator and then immediately be elected to the Chamber of Deputies, thus ensuring a 9-year period in congress, equal to three consecutive terms in the lower chamber. Lujambio ${ }^{61}$ disputes these opinions with evidence showing that between 1933 and 1995, only 379 (9\%) out of 4,227 PRI MGs have been reelected (either by moving from one chamber to the other, or being elected again in a non consecutive period) at least once. Similar information for the

${ }^{60}$ Kenneth A. Shepsle \& Mark S. Bonchek, Analyzing Politics. Rationality, Behavior And Institutions (W.W. Norton and Company, INC) (1997).

${ }^{61}$ Alonso Lujambio, Federalismo y Congreso en el Cambio Político de México (Instituto de Investigaciones Jurídicas, Universidad Nacional Autónoma de México) (1996). 
PAN demonstrates that only 52 (11\%) of 455 MGs from this party have been reelected since 1946.

Therefore, I propose reinstating consecutive reelection in both chambers, in the lower chamber for a maximum of three terms (12 years), and make it concide with one consecutive reelection in the senate (2 periods of 6 years). By granting greater independence from the centralized influence of their political parties, MCs will be able to redirect their attention to their constituents. This reform further aims at making MCs more accountable and more identifiable to citizens since less than the $5 \%$ of the population know who their representatives in congress are.

Although I am well aware of the perils that some scholars associate with reelection, I am confident that the advantages are greater than the disadvantages.

\section{G. Fostering Cooperation among Branches}

Of all the threats to the system and proposals to remedy the situation, I consider fostering cooperation the most complex. As discussed in the first section of this article, the separation of powers can bring some positive effects (checks and balances) to the regime, but it also has some negative aspects, the most contentious being the lack of cooperation among the different branches of power. We have discussed throughout this article we have given the historical and institutional reasons behind the breakdown of Mexico's institutional engineering.

Some scholars propose that presidential systems should abandon such institutional arrangements and move towards a parliamentary system (i.e. Linz, Valenzuela). ${ }^{62}$ Others have hinted that semi-presidential systems are more stable and solve some of the core problems of presidential systems (i.e. Elgie [1999, 2007], Sartori [1994, 1997], Lijphart [1994]).

Changing institutional arrangements from one system to another depends on specific aspects inherent to each country (history, momentum, balance of power, and so on). Sartori ${ }^{63}$ presents an alternative to the multi-cited systems: "alternating presidentialism" or "intermittent presidentialism." This system entails what he calls a "double engine," that is, a parliamentary system as the primary engine and a presidential system to be implemented when the former fails.

Sartori $^{64}$ proposes this type of institutional arrangement for Mexico, stating that it would suit the country better than a semi-presidential system: "my suggestion [...] relates to the stage at which Mexico will be confronted with the reinforcement of parliament and executive-level transformation." ${ }^{95}$ Even

\footnotetext{
${ }^{62}$ Linz, supra note 6.

${ }^{63}$ Sartori, supra note 5.

${ }^{64} \mathrm{Id}$.

${ }^{65} I d$.
} 
though I concur with Sartori's "prediction" that Mexico would face the challenge of reinforcing parliament, as is the case today, I do not fully agree that it would be easy to implement this particular arrangement because presidential and parliamentary system constitutions simply require the presence of a prime minister or president, respectively. I believe alternating presidentialism would be difficult to understand and complicated to implement. It would most likely not be seen as a positive change, but rather an institutional breakdown.

Sartori's proposal would increase competition since the president would be waiting for the parliamentary system to fall apart so he can take it over. Therefore, I propose an alternative solution that could foster cooperation among institutions: unlike "alternating" systems, this would entail "coexistence" so that the system can work as a presidential or semi-presidential one in terms of election results. This could be achieved by instating three features: (i) a Head of Congress; (ii) congressional ratification of cabinet members; and (iii) line item veto and earmarked (preferential) initiatives. ${ }^{66}$

A Head of Congress ( $\mathrm{HC}$ ) has to some extent already been included in the Mexican Constitution, which names the president of the Chamber of Deputies the president of the congress. Therefore, only a slight change in name would illustrate the change in its new functions. The $\mathrm{HC}$ would be selected from the $500 \mathrm{MCs}$ and elected by a two-thirds vote in the chamber, thus garnering the confidence and support of the legislature. The president of the Chamber of Deputies would remain in place and aid the $\mathrm{HC}$ with procedural duties of the chamber. The HC's main function would be to act as a liaison between the executive and legislative branches. The HC would be included in cabinet meetings but not have a vote. In situations of a divided government, the HC could find common ground to put forward a shared agenda, or simply champion the congress agenda. In such cases, the government would be more semi-presidential.

Cabinet ratification by the legislature is nothing new. My specific proposal is to introduce the ratification process as a constitutional requirement. Appointments would still be a presidential prerogative, but the cabinet would be ratified by a simple majority vote in the chamber. A recent collaborative study carried out by the Institute for Legal Research of the National Autonomous University of Mexico (UNAM) and the Mexican Senate proposed that certain cabinet members (those deemed as being more involved in national and foreign policy) should be ratified by the Senate and others, by the Chamber of Deputies. Although I do not focus on the role of the Senate in this article, I subscribe to this combined process of ratification for cabinet members. Dis-

${ }^{66}$ By the time this article was written, the Mexican congress began discussions regarding political reform that touches upon certain aspects addressed in this article, such as the reelection, line item veto, earmarked initiative and ratification of cabinet by congress, among others. Before the publication of the article, congress enacted a constitutional reform (November 2011 ) introducing some of these features while leaving others for further analysis and deliberation. 
missal should still be the prerogative of the executive, but if two thirds of the cabinet opposes the dismissal, the HC would then have the decisive vote.

Finally, line item veto and earmarked or preferential initiative should be introduced. Even though the presidential power of absolute veto tends to reinforce the executive's power (control over the legislative process), an absolute veto tends to reduce the likelihood of its being implemented. Also, an absolute veto dismisses an entire initiative when perhaps most of it might be approved or even desired by the president. With a line item veto, the president would be able to publish pieces of good legislation and remove (veto) the unsustainable parts, without having to restart the complete legislative process. In terms of preferential initiatives, this has been also proposed by the president. Just as the so-called "pocket veto" was recently eliminated from the constitution thus prohibiting the president from keeping an initiative approved by congress from being published, the preferential initiative would allow the president to present a specified number of initiatives per legislature for congress to discuss in a timely manner. This would prevent congress from having gatekeeper powers over relevant initiatives.

Table 5 shows the possible scenarios for the proposed reforms. The most likely outcome is scenario number 3 , as a runoff tends to create a coalition government and a coalition may be expected to perform the same way it does in congress. However, if citizens decide to split their votes (as has been happening), scenario number 4 would be more likely. The third column shows that in scenarios 1 and 3, the system would be expected to work like a presidential system - though with a coalition in the former. Meanwhile, scenarios 2 and 4 would be under a more semi-presidential system under the leadership of an HC (or prime-minister in semi-presidential systems), which according to Elgie and Moestrup ${ }^{67}$ would be the most desirable outcome - at least under a semi-presidentialism system.

Table 5. Possible Scenarios under the New Institutional ARRAngements

\begin{tabular}{|l|c|c|c|}
\hline & \multicolumn{3}{|c|}{ Electoral Outcomes } \\
\hline Scenario 1 & Executive & Legislative & System Type \\
\hline Scenario 2 & Single Party & Majority & Presidential \\
\hline Scenario 3 & Coalition & Majority Coalition & $\begin{array}{c}\text { Presidential/coalition } \\
\text { in government } \\
\text { shared power }\end{array}$ \\
\hline Scenario 4 & Coalition & No Majority & $\begin{array}{c}\text { Semi-presidential/ } \\
\text { shared power }\end{array}$ \\
\hline
\end{tabular}

${ }^{67}$ Robert Elgie \& Sophia Moestrup, The Choice of Semi-Presidentialism and its Consecuences, in Semi-Presidentialism Outside Europe. A Comparative Study 237-248 (Robert Elgie \& Sophia Moestrup eds., Routledge) (2007). 
In an effort to rectify some discrepancies that may result from the separation of powers, I believe a combination of the three reforms can reinforce both the executive and legislative branches, as well as, and more importantly, foster cooperation among institutions under a different set of institutional arrangements. Depending on the specific circumstances (stemming from electoral results), the system may work as a purely presidential system while in others, it may work like semi-parliamentary system.

\section{Conclusions}

Over the past two decades, the Mexican political system has undergone several reforms to adapt the presidential regime to the new conditions of pluralism and citizens' increased demands for accountability. As a result, the system has experienced a significant transformation on establishing more democratic institutions. Granting independence to each of these institutions to ensure an effective separation of powers has clearly been a positive step towards democratization in Mexico, despite its long history of authoritarian regimes. With the new balance of power and institutional setting, the system has succeeded in becoming an electoral democracy, but still does not have adequate institutional engineering.

Since the PRI instituted electoral reforms that were mainly aimed at enhancing the party's power over other institutions and were reactions to the political atmosphere of the time and growing demands from the opposition, the reforms had some unexpected outcomes and thus the path towards democracy has been harmful. Regardless of the debate as to which system is better or more effective, institutional arrangements under presidentialism generally present some dangers that need to be addressed. The Mexican system is no exception, though I believe a measured shift toward a parliamentary system would be less dramatic and therefore preferable.

My proposal attempts to correct certain discrepancies that persist in the institutional engineering of Mexico's presidential system by: (i) introducing a second-round runoff to address issues of legitimacy; (ii) introducing reelections so that MCs become more accountable to their constituencies than being mainly guided by party interests as mere policy-seekers; and (iii) establishing a new institutional setting that would foster cooperation among branches by instituting: a) a "Head of Congress", which would be in charge of the liaison with the executive and occasionally embrace further responsibilities (when the system becomes more semi-presidential); b) the requirement of cabinet ratification by the congress to create a sense of co-responsibility in the executive's performance, and; c) the line item veto and preferential or earmarked initiative leading to a more timely legislative process for structural reforms. 
These are not only desirable reforms for better government performance and political stability in Mexico; they are also feasible since they do not require major changes in institutional arrangements. Some proposals have already been proposed and are gaining more and more support in the political sphere and more importantly from the civil society. 